\title{
Kicking Center
}




\section{Critical Issues in Sport and Society}

\section{Michael Messner and Douglas Hartmann, Series Editors}

Critical Issues in Sport and Society features scholarly books that help expand our understanding of the new and myriad ways in which sport is intertwined with social life in the contemporary world. Using the tools of various scholarly disciplines, including sociology, anthropology, history, media studies and others, books in this series investigate the growing impact of sport and sportsrelated activities on various aspects of social life as well as key developments and changes in the sporting world and emerging sporting practices. Series authors produce groundbreaking research that brings empirical and applied work together with cultural critique and historical perspectives written in an engaging, accessible format.

Rachel Allison, Kicking Center: Gender and the Selling of Women's Professional Soccer

Jules Boykoff, Activism and the Olympics: Dissent at the Games in Vancouver and London

Diana Tracy Cohen, Iron Dads: Managing Family, Work, and Endurance Sport Identities

Cheryl Cooky and Michael A. Messner, No Slam Dunk: Gender, Sport, and the Unevenness of Social Change

Jennifer Guiliano, Indian Spectacle: College Mascots and the Anxiety of Modern America

Kathryn E. Henne, Testing for Athlete Citizenship: Regulating Doping and Sex in Sport

Jeffrey L. Kidder, Parkour and the City: Risk, Masculinity, and Meaning in a Postmodern Sport

Michael A. Messner and Michela Musto, eds., Child's Play: Sport in Kids' Worlds

Jeffrey Montez de Oca, Discipline and Indulgence: College Football, Media, and the American Way of Life during the Cold War

Stephen C. Poulson, Why Would Anyone Do That? Lifestyle Sport in the Twenty-First Century

Nicole Willms, When Women Rule the Court: Gender, Race, and Japanese American Basketball 


\section{Kicking Center}

Gender and the Selling of Women's Professional Soccer

RACHEL ALLISON

\section{Til}

\section{Rutgers University Press}

New Brunswick, Camden, and Newark, New Jersey, and London 
Library of Congress Cataloging-in-Publication Data

Names: Allison, Rachel, author.

Title: Kicking center : gender and the selling of women's professional soccer / Rachel Allison. Description: New Brunswick, New Jersey : Rutgers University Press, [2018] | Series: Critical issues in sport and society | Includes bibliographical references and index.

Identifiers: LCCN 2017033843 | ISBN 9780813586786 (cloth : alk. paper) |

ISBN 9780813586779 (pbk. : alk. paper)

Subjects: LCSH: Soccer for women-United States. | Women soccer players-United States. |

Soccer for women-Social aspects-United States. | Soccer-Social aspects-United States.

Classification: LCC GV944.5 .A44 2018 | DDC 796.334-dc23

LC record available at https://lccn.loc.gov/2017033843

A British Cataloging-in-Publication record for this book is available from the British Library.

Copyright $\odot 2018$ by Rachel Allison

All rights reserved

No part of this book may be reproduced or utilized in any form or by any means, electronic or mechanical, or by any information storage and retrieval system, without written permission from the publisher. Please contact Rutgers University Press, I06 Somerset Street, New Brunswick, NJ 0890 . The only exception to this prohibition is "fair use" as defined by U.S. copyright law.

(क)

The paper used in this publication meets the requirements of the American National Standard for Information Sciences-Permanence of Paper for Printed Library Materials, ANSI Z 39.48-1992.

www.rutgersuniversitypress.org

Manufactured in the United States of America 
For Grant and Lynne Allison 
